\title{
Attack of Microcystis aeruginosa bloom on a Ceratophyllum submersum field: Ecotoxicological measurements in real environment with real microcystin exposure
}

\author{
Andrea Zsuzsanna Ujvárosi ${ }^{\mathrm{a}, \mathrm{b}}$, Milán Riba ${ }^{\mathrm{a}, \mathrm{b}}$, Tamás Garda ${ }^{\mathrm{a}, \mathrm{b}}$, Gyöngyi Gyémánt ${ }^{\mathrm{a}, \mathrm{c}}$, György Vereb ${ }^{\mathrm{a}, \mathrm{d}}$, \\ Márta M-Hamvas $^{\mathrm{a}, \mathrm{b}, 1}$, Gábor Vasas ${ }^{\mathrm{a}, \mathrm{b}, 1}$, Csaba Máthé , $^{\mathrm{a}, \mathrm{b}, *, 1}$ \\ ${ }^{a}$ University of Debrecen, Egyetem ter 1, H-4032 Debrecen, Hungary \\ ${ }^{\mathrm{b}}$ Faculty of Science and Technology, Institute of Biology and Ecology, Department of Botany, Hungary \\ ${ }^{\mathrm{c}}$ Faculty of Science and Technology, Institute of Chemistry, Department of Inorganic and Analytical Chemistry, Hungary \\ ${ }^{\mathrm{d}}$ Faculty of Medicine, Department of Biophysics and Cell Biology, Hungary
}

\section{A R T I C L E IN F O}

\section{Article history:}

Received 14 October 2018

Received in revised form 20 December 2018

Accepted 21 January 2019

Available online xxx

Editor: Julian Blasco

Keywords:

Microcystins

HAB

Real exposure

Ceratophyllum submersum

Histone $\mathrm{H} 3$ phosphorylation

Cell death

\begin{abstract}
A B S T R A C T
Overproduction of toxic cyanobacteria is a type of harmful algal blooms (HABs). The heptapeptide microcystins (MCs) are one of the most common cyanotoxins. There is increasing research concerning the effects of MCs on growth and physiology of vascular plants, however there is a lack of studies on their direct effects on aquatic macrophytes in the real environment. Here we report the occurrence of a MC producing HAB in Lake Bárdos, Hungary in 2012 with harmful effects on cytological, histological and biochemical parameters of Ceratophyllum submersum (soft hornwort) plants naturally growing at the blooming site. Blue-Green Sinapis Test (BGST) showed high toxicity of HAB samples. Cell-free water samples contained a significant amount of MCs $\left(7.31 \pm 0.17 \mu \mathrm{g} \mathrm{L}^{-1}\right)$ while $C$. submersum plants contained $1.01 \pm 0.21 \mu \mathrm{gg} \mathrm{DW}{ }^{-1}$ MCs. Plants showed significant increases of protein content and decreases of anthocyanin content and carotenoid/chlorophyll ratio, indicating physiological stress- as compared to plants from the control (MC free) sampling site of the same water body. Histological and cytological studies showed (i) radial swelling and the abnormal formation of lateral buds at the shoot tip leading to abnormal development; (ii) the fragmentation of nuclei as well as accumulation of phenolics in the nucleus indicating that the HAB induced cell death and stress reactions at the nuclear level. The most relevant effect was the increase of histone H3 phosphorylation in metaphase chromosomes: since MCs are strong inhibitors of protein phosphatases, this alteration is related to the biochemical targets of these toxins. The HAB decreased peroxidase activity, but increased nuclease and protease activities, showing the decreased capacity of plants to face biotic stress and as the cytological changes, the induction of cell death. This study is one of the first to show the complex harmful changes in aquatic plants that co-exist with $\mathrm{HABs}$.
\end{abstract}

\section{Introduction}

Nowadays, one of the main environmental hazards of anthropogenic origin is freshwater eutrophication. This phenomenon is frequently accompanied with severe algal and cyanobacterial overproduction called water blooming (Carmichael, 1992). Many cyanobacterial genera are able of producing a wide range of secondary metabolites with adverse effects on mammals, birds, and fish and even plants. The potential hazards of cyanotoxins in aquatic ecosystems were already pointed out at the early stage of relevant research (Carmichael, 1992). These cyanotoxins are a serious risk for human health, because human organism may be affected by drinking water obtained from contaminated freshwaters or by consuming organisms

\footnotetext{
* Corresponding author at: University of Debrecen, Egyetem ter 1, H-4032 Debrecen, Hungary.

Email addresses: hamvas.marta@science.unideb.hu (M. M-Hamvas); vasas. gabor@science.unideb.hu (G. Vasas); mathe.csaba@science.unideb.hu (C. Máthé)

1 These authors contributed equally to the manuscript.
}

living in such water bodies. Among these metabolites, microcystins (MCs) are one of the most abundant and well studied compounds (Campos and Vasconcelos, 2010). MCs are a family of hepatotoxic heptapeptides with potent inhibitory effects on type 1 and 2A protein phosphatases (PP1 and PP2A) (and other, minor serine-threonine phosphatases). They are also strong inducers of oxidative stress in the affected organisms (see Máthé et al., 2016 for a review).The variability of MC congeners comes from variable amino acids that do not affect significantly their biochemical effects (Campos and Vasconcelos, 2010). MCs are produced by various cyanobacterial genera including Microcystis, Anabaena, Lyngbya or Planktothrix (Wiegand and Pflugmacher, 2005).

Submerged and floating macrophytes play central role in aquatic ecosystems as the main primary producers. Early studies have already shown that aquatic macrophytes (for example Ceratophyllum demersum, Elodea canadensis, Vesicularia dubyana and Phragmites australis) are able of MC uptake (Pflugmacher et al., 1999, 2001), but most of these studies were conducted laboratory experiments. A more recent study shows relatively efficient uptake of MCs for Ceratophyllum inflatum, C. demersum and Potamogeton maackianus naturally 
co-existing with a MC containing bloom (Jia et al., 2016). The adverse effects of MCs on these organisms were studied at histological, cytological and biochemical levels. Some of the most important effects are: growth inhibition, root/shoot necrosis, microtubule disorganization, chromatin condensation and fragmentation/programmed cell death and related to the latter, alterations in the activities of antioxidant enzymes, nucleases and proteases (Babica et al., 2006; Máthé et al., 2013 and many other works). It should be noted however, that nearly all of these studies used laboratory experiments where plant growth and cyanotoxin exposure were controlled and showed only indirectly the real effects of MCs on aquatic plants in the real environment. To date, there is still a need for studies on the direct effects of cyanotoxins on aquatic plant communities in the environment. For vertebrates (mainly fish species), several real environmental studies are already available (Tokodi et al., 2018) and it is suggested that MCs found in vertebrate organisms are accumulated via aquatic plants and invertebrates through the food web (Bownik, 2016). The importance of real environmental studies on aquatic macrophytes has been recognized for a long time. Körner (2001) pointed out that one of the serious impacts of eutrophication of aquatic ecosystems is the disappearance of submerged macrophytes and the shift to a phytoplankton-dominated state. Pflugmacher (2002) has shown that in several of the lakes of Berlin and Brandenburg, Germany, due to the mass development of cyanobacteria producing varying concentrations of secondary metabolites or cyanotoxins, none of the higher aquatic plants such as pondweed (Potamogeton sp.), coontail (Ceratophyllum demersum), spatterdock (Nuphar luteum), or even the very common duckweed (Lemna sp.) could be found. He raised the question whether cyanobacterial toxins could act as allelopathic chemicals in the aquatic ecosystem.

In the light of the above statements, our principal aim was to investigate the real environmental effects of MCs on aquatic macrophytes. For this task, we chose a relatively small lake in SE Hungary, where occasional cyanobacterial blooms (harmful algal blooms, HABs) co-occurring with a large population of Ceratophyllum submersum (soft hornwort, a submerged vascular plant) were reported previously by personal communications (thus, both years without and with blooming occurred). We analyzed possible histological, cytological and biochemical changes induced in plants by the toxin-containing freshwater body, to have a complex picture about the harmful effects of toxic cyanobacteria. To our best knowledge, this is one of the first studies reporting real-environment cyanotoxin-plant interaction.

\section{Materials and methods}

\subsection{Site description and sampling-sample collection and analysis}

All samples of this study were collected from the Hungarian Lake Bárdos (area: 3 ha, average depth: 1.5-2m. GPS: 46.634958, 21.270314 for the blooming site and $46.634626,21.269220$ for the control site, Fig. 1a). The phytoplankton samples were collected from the superficial layer, at the sites where Ceratophyllum submersum plant samples and water samples were collected from the area of the water bloom and from a distant, control area, each on late summer-early autumn periods. Phytoplankton and water samples were collected between 2011 and 2013, while C. submersum samples were collected in 2012. Morphological characteristics of cyanobacterial species were identified and classified according to Komárek and Anagnostidis (1998), with light microscopy at a magnification of $250 \times$ (Carl Zeiss Jenamed2).

The lyophilized phytoplankton (cyanobacterial) samples (10-10 mg DW) from the water blooms were extracted using deionized ultrapure water, while stirring and sonicating several times at room temperature for $6 \mathrm{~h}$. Water was used, since it is well-known that efficiency of MC extraction is similar for water and methanolic extraction and water is readily used for the analysis of cyanobacterial MC content (Kim et al., 2009). Moreover, the ELISA method used in the present study requires an aqueous system (see below). Subsequently, the samples were centrifuged at $13000 \mathrm{rpm}$ for $5 \mathrm{~min}$ (Heraeus Biofuge). Supernatant was collected and stock solutions for ELISA and plant toxicity tests were prepared at a concentration of $0.2 \mathrm{mg} \mathrm{mLDW}^{-1}$. The lyophilized water samples from the $\mathrm{HAB}$ and control site were dissolved in deionized ultrapure water and a $66.66 \mathrm{mg} \mathrm{DW} \mathrm{mL}^{-1}$ stock solution for ELISA test was prepared. For the determination of cyanotoxin content, plant samples were extracted using $99.8 \%$ methanol at a volume three times the fresh weight of the plant samples. Then samples were stirred and left at $4{ }^{\circ} \mathrm{C}$ overnight, subsequently were centrifuged at $5000 \mathrm{rpm}$ for $5 \mathrm{~min}$ (Heraeus Biofuge), and the supernatant was collected. Methanol was added again to pelleted plant material at a volume one and a half times the fresh weight of the sample. They were incubated at $4{ }^{\circ} \mathrm{C}$ for $4 \mathrm{~h}$ while stirring, then were centrifuged at $5000 \mathrm{rpm}$ for $5 \mathrm{~min}$, and supernatants were collected. Methanol is the standard solvent for efficient extraction of MCs and other secondary metabolites from fresh (non-lyophilized) plant shoots including aquatic plants, since water extraction leaves a large fraction of $\mathrm{MC}$ bound to organic compounds of the plant matrices (Pflugmacher et al., 1999, 2001; Gutiérrez-Praena et al., 2014; Romero-Oliva et al., 2014; Jia et al., 2016). This step was repeated once again, and the combined extracts were concentrated in a rotary evaporator and were dissolved in $3 \mathrm{~mL}$ deionized ultrapure water for stock and for ELISA tests.

Quantitative measurement of total microcystin content in water bloom, water as well as Ceratophyllum submersum plant samples were carried out by Adda specific Microcystins indirect competitive ELISA kit (Enzo Life Sciences; ALX-850-319-KI01) according to the manufacturer's instructions. Stock solutions of the plant extracts were $5 \times, 50 \times$ and $500 \times$ diluted. From the stock solution $\left(0.2 \mathrm{mg} \mathrm{DW} \mathrm{mL}^{-1}\right)$ of cyanobacterial extracts $40,4,0.4,0.04 \mu \mathrm{g} \mathrm{mL}^{-1}$ concentrations were applied to the ELISA kit, using deionized ultrapure water as solvent control. Water samples $\left(0.133,1.33\right.$ and $\left.6.66 \mathrm{mgDWm}^{-1}\right)$ of the stock were prepared from lyophilized water. Samples were analyzed in three individual measurements. Standards of the kit $\left(0-5 \mu \mathrm{gL}^{-1}\right)$ were applied as calibrators. Positive control was included in the kit at $0.75 \pm 0.185 \mu \mathrm{g}$ microcystins $\mathrm{L}^{-1}$. Optical density values were measured at $450 \mathrm{~nm}$. Microcystins concentrations were calculated manually by interpolating from linear standard curves plotting the results of calibrators and the negative control.

For biochemical analyses, collected plant samples were washed several times in tap water then in sterilized tap water and after blotting they were frozen in liquid nitrogen and stored at $-70^{\circ} \mathrm{C}$ until analysis. For histological and cytological analyses, the freezing step was avoided (see below for details).

\subsection{Purification and identification of cyanotoxins}

In 2012, lyophilized phytoplankton samples dominated by $\mathrm{Mi}$ crocystis sp. $(7.38 \mathrm{~g})$ were extracted overnight with $99.8 \%$ methanol $(260 \mathrm{~mL})$ at room temperature with continuous stirring. After centrifugation (13,000 rpm, $20 \mathrm{~min}$, Beckman Avanti J-25 centrifuge), the pellet was washed once again with $50 \mathrm{~mL} 99.8 \%$ methanol for $60 \mathrm{~min}$ and centrifuged again. The combined supernatant was concentrated in a rotary evaporator (Scilogex RE100-Pro) at $40^{\circ} \mathrm{C}$. The residue was dissolved in $10 \mathrm{mM}$ Tris- $\mathrm{HCl}(\mathrm{pH} 7.5)$, centrifuged at $13000 \mathrm{rpm}$ for $15 \mathrm{~min}$. The supernatant solution was filtered $(\mathrm{GF} / \mathrm{C}$, 
(a)

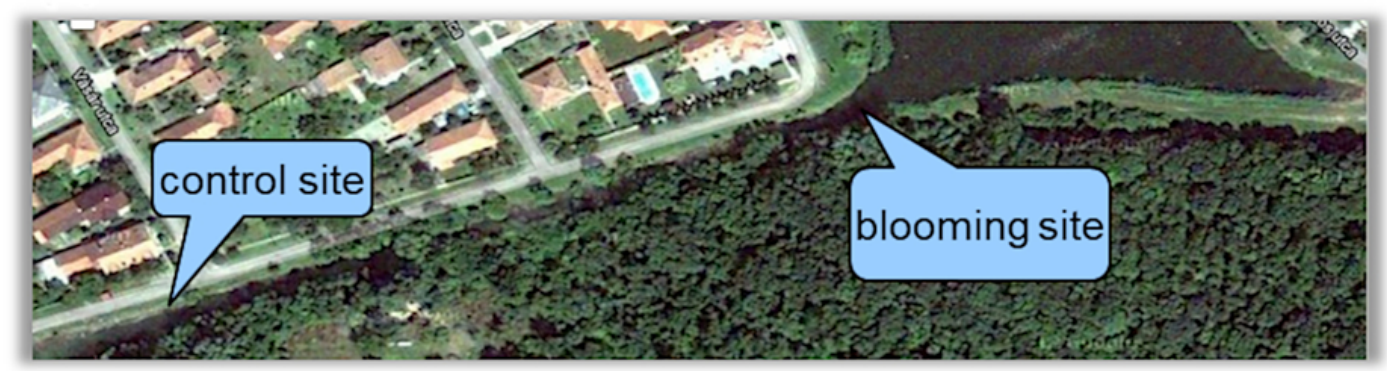

(b)
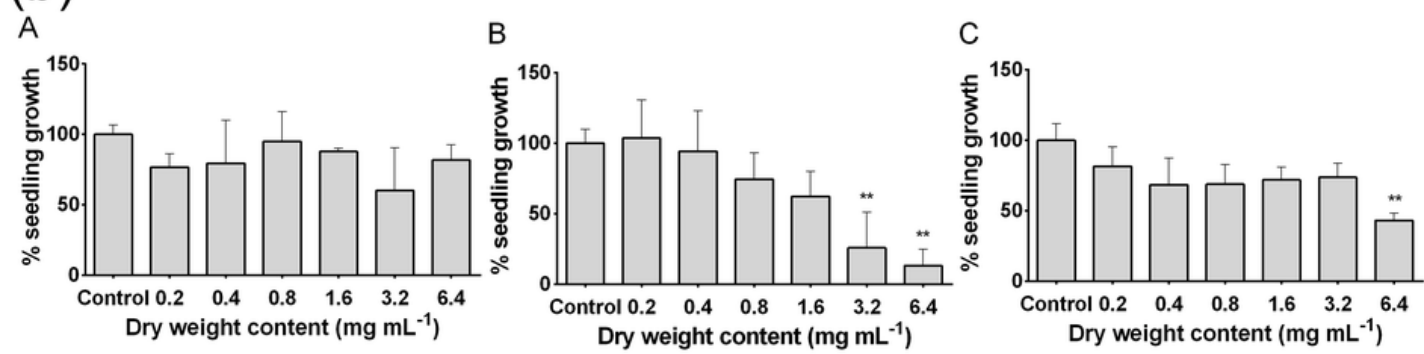

(c)

A

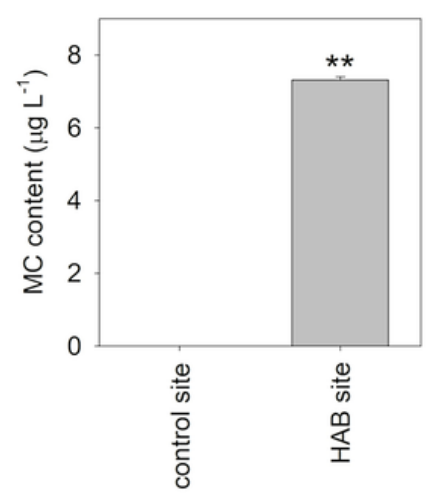

B

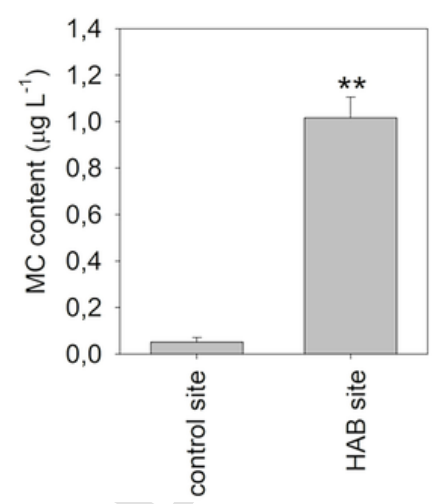

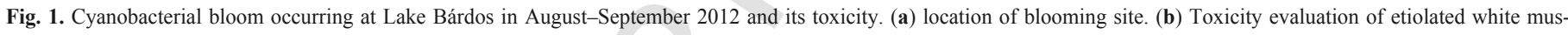

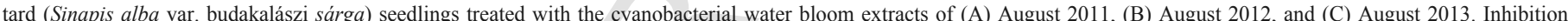

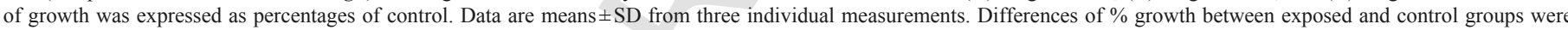

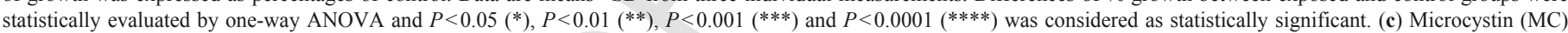

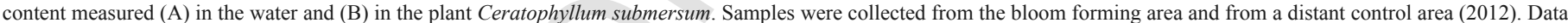
are means \pm SD from three individual measurements.

Whatman) and loaded onto a DEAE-cellulose ion exchange column (Whatman) equilibrated with $10 \mathrm{mM}$ Tris-HCl (pH 7.5). During separation, the column was eluted with $10 \mathrm{mM}$ Tris- $\mathrm{HCl}$ containing $0-100 \% 0.2 \mathrm{M} \mathrm{NaCl}$ linear gradient and with a $5 \mathrm{~mL} \mathrm{~min}^{-1}$ flow rate (Pharmacia FRAC-300 fraction collector), the absorbance was measured at $240 \mathrm{~nm}$ (BOECO S-22 UV/VIS). Fractions were concentrated by evaporation (rotary evaporator). This ion-exchange chromatography method proved to be very efficient for the separation of different congeners of $\mathrm{MC}$ : these cyanotoxin variants eluted at different $\mathrm{NaCl}$ concentrations according to their ionic properties. The interaction of these different congeners on the anion exchanger was weak, thus only a low ion strength (as for DEAE-cellulose) is appropriate to eluate these metabolites, moreover MCs usually separated easily from the other types of metabolites (see Kós et al., 1995; Somdee and Somdee, 2015 as well). The identification of MC congeners was per- formed essentially as described previously (Farkas et al., 2014), with modifications. The samples were examined in positive-ion mode using a Bruker Biflex MALDI-TOF mass spectrometer equipped with delayed-ion extraction. A $337 \mathrm{~nm}$ nitrogen laser was used for desorption/ionization of the sample molecules. Spectra from multiple (at least 100) laser shots were summarized using $19-\mathrm{kV}$ accelerating and $20-\mathrm{kV}$ reflectron voltage. External calibration was applied using the $[\mathrm{M}+\mathrm{Na}]+$ peaks of cyclodextrins with DP $6-8 \quad(\mathrm{~m} / \mathrm{z}$ 995.311157.361319.41 Da). The measurement was performed in 2,5-dihydroxybenzoic acid (DHB) matrix, by mixing $0.5 \mu \mathrm{L}$ of matrix solution with $0.5 \mu \mathrm{L}$ of sample on the sample target and allowing it to dry at room temperature. DHB matrix solution was prepared by dissolving DHB $(10 \mathrm{mg})$ in a mixture $(0.5 \mathrm{~mL})$ of ethanol and water $(1: 1, \mathrm{v}: \mathrm{v})$. The compounds were identified on the basis of the $\mathrm{m} / \mathrm{z}$ of $[\mathrm{M}+\mathrm{H}]^{+}$peaks. 


\subsection{Blue Green Sinapis test}

The Blue Green Sinapis Test (mustard test, BGST) (Kós et al., 1995; Vasas et al., 2002) was performed with minor modifications to measure the inhibition of plant growth caused by cyanobacterial extracts. Samples were added into sterile 96-well microtiter plates and complemented with sterile agar to a final concentration of $10 \mathrm{mg} \mathrm{DW} \mathrm{mL}^{-1}$. Dry seeds (Sinapis alba var. Budakalászi sárga) were seeded onto agar and grown in the dark at $28^{\circ} \mathrm{C}$ for $72 \mathrm{~h}$ in a sterile metal box. The length of etiolated seedlings was measured. Fifty percent of inhibition of plant growth $\left(\mathrm{IC}_{50}\right)$ was calculated when necessary. The concentrations of cyanobacterial (phytoplankton) extracts applied to measure the inhibition were $0.20,0.40,0.80,1.60,3.20$, $6.40 \mathrm{mg} \mathrm{DW} \mathrm{mL}^{-1}$. Sterile ultrapure water was applied as control. Independent experiments were repeated three times. Statistical significance between treated groups and the control was determined by one-way analysis of variance (1-way ANOVA) and $P<0.05(*)$, $P<0.01(* *), P<0.001(* * *)$ were considered as statistically significant (GraphPad Prism 6 software, San Diego, California, USA).

\subsection{Measurement of pigment content of Ceratophyllum samples}

Total chlorophyll and carotenoid contents of $80 \%$ acetone extracts of samples were assayed using the method of Wellburn (1994) as it was described by Szöllösi et al. (2010). The total anthocyanin contents of plants were measured spectrophotometrically (Shimadzu $1601 \mathrm{~A}$ spectrophotometer) as we described earlier (M-Hamvas et al., 2003). The total chlorophyll/carotenoid and anthocyanin content of plants were calculated as $\mu$ g chlorophyll/carotenoid $\mathrm{mg}^{-1}$ fresh weight and $\mu$ mol total anthocyanin $g^{-1}$ fresh weight and were expressed in the percentage of "control" (C. submersum plants collected from control site).

\subsection{Protein content, peroxidase-, nuclease- and protease activities of cell-free extracts of Ceratophyllum samples}

Ceratophyllum samples were pulverized in liquid nitrogen and homogenized in a buffer containing $150 \mathrm{mM} \mathrm{NaCl}$ (Reanal, Budapest, Hungary) and 14.6 mM 2-mercaptoethanol (Sigma-Aldrich, St. Louis, Mo., USA) in $100 \mathrm{mM}$ Tris-HCl (Sigma-Aldrich) pH 8.0 (Schlereth et al., 2000). To disintegrate remaining organelles, homogenates were subjected two times to a freezing-thawing procedure, then centrifuged (15,000 rpm, $10 \mathrm{~min}$, Beckman Avanti J-25 centrifuge) at $4{ }^{\circ} \mathrm{C}$ and supernatants were used as crude protein extracts. The protein contents of cell-free extracts were assayed according to Bradford (1976) using bovine serum albumin as standard.

For the determination of peroxidase (POD, EC.1.11.1.) activity the oxidation of pyrogallol $\left(20 \mathrm{mM}, \varepsilon_{420}: 2.47 \mathrm{mM}^{-1} \mathrm{~cm}^{-1}\right.$, Reanal, Budapest, Hungary) in the presence of $10 \mathrm{mM} \mathrm{H}_{2} \mathrm{O}_{2}$ (Reanal, Budapest, Hungary) was measured spectrophotometrically (Shimadzu $1601 \mathrm{~A}$ spectrophotometer) in a reaction medium containing $50 \mathrm{mM}$ potassium-phosphate $\left(\mathrm{K}_{2} \mathrm{HPO}_{4} / \mathrm{KH}_{2} \mathrm{PO}_{4}\right)$ buffer $(\mathrm{pH} 7.5)$ as we described earlier (M-Hamvas et al., 2010). The reaction was initiated by addition of protein sample $(0,5-2 \mu \mathrm{g}$ protein in $2-5 \mu \mathrm{l}$ crude extract to $990 \mu 1$ reaction mixture) and the elevated amount of oxydized pyrogallol was measured for $30 \mathrm{~s}$. The enzyme activity was calculated as mM oxidized pyrogallol min ${ }^{-1} \mathrm{mg}^{-1}$ protein and was expressed in the percentage of the control activities. For the analysis of POD isoenzyme pattern, $7 \mu \mathrm{g}$ protein was loaded onto each well of native $7.5 \%$ (w/v) polyacrylamide gels. Electrophoresis was performed at $4{ }^{\circ} \mathrm{C}$, followed by gel washing for $60 \mathrm{~min}$ in $50 \mathrm{mM}$ potassium-phosphate buffer pH 7.5 and staining in $49 \mathrm{~mL}$ potassium-phosphate buffer containing $25 \mu \mathrm{L} 30 \% \mathrm{H}_{2} \mathrm{O}_{2}$ and $0,126 \mathrm{~g}$ pyrogallol dissolved in $1 \mathrm{~mL}$ water. Bands with enzyme activities became visible due to dark-coloured oxidized pyrogallol.

The detection of single-strand preferring nuclease (SSP nuclease, ssDNase: EC 3.1.30.1) activities was performed as we described earlier (M-Hamvas et al., 2003; Jámbrik et al., 2011). Protein samples were dissolved in the sample buffer described by Laemmli (1970) and they were incubated at room temperature for $10 \mathrm{~min}$ and loaded without boiling to polyacrylamide gels containing $10 \mu \mathrm{g} \mathrm{mL}^{-1}$ heat denatured (for ssDNase activities) or intact chicken blood DNA (for dsDNase activities). $18 \mu \mathrm{g}$ protein was loaded onto each well of $10 \%$ and $7.5-12.5 \%$ linear sodium dodecyl sulfate gradient gels. Plant samples were loaded together with a molecular weight marker (ProSieve ${ }^{\circledR}$ QuadColor ${ }^{\mathrm{TM}}$ Protein Marker, $4.6 \mathrm{kDa}-300 \mathrm{kDa}$, Lonza Rockland, Inc. USA). Gel electrophoresis was performed according to Laemmli (1970). After electrophoresis, enzymes were renatured for $30 \mathrm{~min}$ in water, then by three washes in a buffer containing $10 \mathrm{mM}$ Tris-HCl, pH 6.8 and 20\% (v/v) 2-propanol, followed by washing in Tris-HCl, pH 6.8. For the detection of nuclease isoenzymes, gels were incubated (generally for $14-24 \mathrm{~h}, 39^{\circ} \mathrm{C}$ ) in Tris-HCl, $\mathrm{pH} 6.8$.

Incubated gels were stained in ethidium bromide solution $\left(0.5 \mu \mathrm{g} \mathrm{mL}^{-1}\right.$, Sigma-Aldrich) and observed in UV light. Nuclease isoenzymes were detected as clear, unstained bands, due to DNA hydrolysis. Their molecular weight was estimated with the aid of UVI-TEC $®$ software and the activities of isoenzymes of three gels were quantified with the CpAtlas ${ }^{\circledR}$ software that calculates the number of square pixels of a given protein band, as we described earlier (Jámbrik et al., 2011). The results are presented in \% of controls.

Protease activity (E.C.3.4.11-19; 3.4.21-25; 3.4.99) analysis of crude protein extracts of $C$. submersum samples (10-20 $\mu 1$ of $9 \mu \mathrm{g}$ protein/well) was carried out using gelatine-containing SDS slab gels according to Schlereth et al. (2000) as we described earlier (Jámbrik et al., 2010). Protein samples were dissolved in SDS-probe buffer without heating and loaded on $10 \%$ SDS-polyacrylamide gels containing $0.04 \%$ gelatine. The gels were run at $4{ }^{\circ} \mathrm{C}$ in dark. To renature proteolytic enzymes, SDS was removed as it was shown previously (see nuclease activity gels). The gels were incubated for $4 \mathrm{~h}$ at $38^{\circ} \mathrm{C}$ in reactivating buffer $(0.1 \mathrm{M}$ sodium phosphate buffer, Reanal, Budapest, Hungary), pH 5.5 with and without $5 \mathrm{mM} \beta$-mercaptoethanol in the dark. Local gelatine degradations were visible after Coomassie blue staining (Coomassie Brilliant Blue R250) and revealed the sites of active proteinases. Relative molecular mass and band intensity were evaluated by UVI-TEC $\AA$ and CpAtlas ${ }^{\circledR}$ softwares as we shown earlier (Jámbrik et al., 2010). Measured parameters were presented in \% of control.

For pigment and protein contents as well as enzyme activities, data were analyzed using the statistical and graphical functions of Sigma Plot 11.0 (USA). In data sets the significant differences $(P<0.05)$ between controls and treatment's means were calculated with Student's $t$-test. The mean values $\pm \mathrm{SE}$ are reported in the figures.

\subsection{Histological and cytological investigations in C. submersum}

C. submersum shoot tips were carefully washed with PBS (phosphate buffered saline), fixed for $16 \mathrm{~h}$ in $4 \%(\mathrm{v} / \mathrm{v})$ formaldehyde (Reanal, Budapest, Hungary) in PBS. Sections of $20-25 \mu \mathrm{m}$ thickness were obtained by cryosectioning with a Leica Jung Histoslide 2000 microtome. Autofluorescence of samples was analyzed with an Olympus Provis AX-70/A Olympus, Tokyo, Japan) conventional fluorescence microscope at an excitation wavelength range of 540- 
$580 \mathrm{~nm}$. Labeling of chromatin with $4^{\prime}, 6^{\prime}$-diamidino-2-phenylindole (DAPI) and immunohistochemical labeling of phospho-Ser10-histone (p-H3 Ser10) were performed as described previously (Szigeti et al., 2009; Beyer et al., 2012). The secondary antibody used for p-H3 Ser10 detection was Alexa 488 (Molecular Probes, Eugene, Oregon, USA). After labeling, microscopical examinations were performed by conventional fluorescence microscopy as well as confocal microscopy (Zeiss LSM 510 confocal microscope, Carl Zeiss Microscopy GmbH, Jena, Germany). For conventional fluorescence microscopy, excitation wavelength was $320-360 \mathrm{~nm}$ (DAPI). For confocal microscopy, excitation wavelengths were $351 / 364 \mathrm{~nm}$ (DAPI) and $488 \mathrm{~nm}$ (Alexa 488). Images of $\mathrm{p}-\mathrm{H} 3$ Ser 10 labeling were quantified by using the facilities of ImageJ software and labeling intensities were expressed as area integrated optical density (AIOD).

For the quantification of histone $\mathrm{H} 3$ phosphorylation, data were analyzed using the statistical and graphical functions of Sigma Plot 11.0 (USA). In data sets the significant differences $(P<0.05)$ between controls and treatment's means were calculated with Student's $t$-test. The mean values $\pm \mathrm{SE}$ are reported in the figure.

\section{Results}

\subsection{Composition of water blooms}

Overall, the phytoplankton was composed of several cyanobacterial species in each period, from which the main bloom forming species were Planktothrix agardhii and Microcystis sp. However, Anabaena spiroides, Anabaena circinalis, and Anabaenopsis hungarica species were observed with low abundance as well. During summer and early autumn of 2011, the dominant bloom forming species was Planktothrix agardhii, although Microcystis, Anabaena and Anabaenopsis species also appeared in the water bloom. We observed difference with the massive presence of Microcystis sp. in the summer-early autumn period of 2012. During summer of 2013 Planktothrix agardhii was again the dominant species with low abundance of Anabaena sp., while during autumn we also observed the presence of Microcystis sp. in the water bloom.

3.2. Analysis of cyanobacterial extracts. Microcystin concentration of water and water bloom phytoplankton samples. Biaccumulation of microcystins in Ceratophyllum submersum

Four different variants of microcystins were detected in the purified cyanobacterial/phytoplankton samples by MALDI-TOF mass spectrometry in 2012. The identified MC congeners were MC-LR, MC-YR, $\left[\mathrm{Dha}^{7}\right] \mathrm{MC}-\mathrm{RR}$ and MC-LY (Table 1).

In August 2012, microcystins were practically not detected in the water samples of control area, while from the area of the water bloom (HAB site) their concentration was $7.31 \pm 0.17 \mu \mathrm{gL}^{-1}$ (Fig. 1c/A). The cyanobacterial extract from August 2012 contained $4.959 \mu \mathrm{g} \mathrm{mg} \mathrm{DW}^{-1}$ microcystins, and from August $20130.449 \mu \mathrm{gmgDW}^{-1}$. On other sampling dates microcystins content was not detected. In August 2012, when MC content of waterbody

Table 1

Microcystin (MC) congeners identified by MALDI-TOF MS in the water bloom of August 2012 .

\begin{tabular}{ll}
\hline Peptide & Molecular weight $(\mathrm{M}+\mathrm{H})$ \\
\hline MC-LR & 995.62 \\
MC-YR & 1046.29 \\
{$\left[\mathrm{Dha}^{7}\right]$ MC-RR } & 1024.27 \\
MC-LY & 1002.28 \\
\hline
\end{tabular}

reached the maximum value at the $\mathrm{HAB}$ site, we measured the following water parameters - conductivity: $647 \mu \mathrm{S} \mathrm{cm}^{-1}, \mathrm{pH}: 7.9$, temperature: $26.4{ }^{\circ} \mathrm{C}$. For the control site, these parameters were - conductivity: $628 \mu \mathrm{S} \mathrm{cm}^{-1}, \mathrm{pH}: 7.9$, temperature: $25.2^{\circ} \mathrm{C}$. Thus, the measurement of the above three parameters showed similar values in the control and HAB sites.

Concentration of microcystins in Ceratophyllum submersum plant sample from the area of the water bloom was $1.01 \pm 0.21 \mu \mathrm{g} \mathrm{DW}^{-1}$, while from the control area it was $0.05 \pm 0.03 \mu \mathrm{g} \mathrm{DW}^{-1}$ (Fig. 1c/B).

\subsection{Growth inhibition of Sinapis alba seedlings}

The etiolated seedlings were measured after $72 \mathrm{~h}$ of exposure. Cyanobacterial extracts from August 2012 and August 2013 significantly inhibited the growth at 3.2 and $6.4 \mathrm{mg} \mathrm{mL}^{-1}$ concentrations, respectively, while the extract from August 2011 (used as negative control, since no MC content in water, phytoplankton or plant was detected in this year) did not affect it at tested concentrations compared to the (water-only)control (Fig. 1b). The sample from August 2012 resulted to be more toxic, where the $\mathrm{IC}_{50}$ was calculated as $2.145 \mathrm{mg} \mathrm{mL}^{-1}$. The growth of seedlings treated with the extract from August 2013 was less inhibited, which resulted a $5.678 \mathrm{mg} \mathrm{mL}^{-1}$ of $\mathrm{IC}_{50}$ (Fig. 1b/B, C).

\subsection{Alteration of biochemical markers in C. submersum-pigment and protein contents}

There were no significant differences in spectrophotometrically analyzed concentrations of photosynthetic pigments of samples (Fig. 2c); the total chlorophyll content was $63.5 \pm 8.8 \mu \mathrm{g} \mathrm{mg} \mathrm{FW}^{-1}$ in $\mathrm{HAB}$ site plants and $59.6 \pm 7.1 \mu \mathrm{g} \mathrm{mg} \mathrm{FW}^{-1}$ in control site plants. The ratio of chlorophyll $a$ to chlorophyll $b$ was practically the same - 0,461 \pm 0.05 and $0,463 \pm 0,04$. Although the concentration of total carotenoids was by about $27 \%$ lower in HAB site plants compared to control ones, this difference was statistically not significant (Fig. 2d). It seems noteworthy, that due to the lower carotenoid content, the ratio of carotenoids to chlorophyll was $0,08 \pm 0,03$ contrarily to $0,46 \pm 0,05$ characteristic for control plants. In contrast to photosynthetic pigments, the anthocyanin concentration of plants in the blooming site was significantly lower $(P<0,001)$ than in plants of the control site (Fig. 2b). The decrease was $>80 \%$ as compared to controls. Soluble protein contents of crude extracts of HAB site's plants were significantly higher $(P<0,001)$ than of the control ones (Fig. 2a).

\subsection{Alteration of histological and cytological markers in $C$. submersum}

Morphological analysis of control C. submersum samples revealed normal shoot tip morphology with nearly equal internode lengths at the shoot dome. This was accompanied by normal chromatin organization in meristematic tissue (Fig. 3a, b). In contrast, samples taken from the HAB site showed altered cell and in consequence, shoot tip swelling and premature development of lateral meristems giving rise to adventitious buds near the shoot tip. Internodes were shortened at the shoot dome (Fig. 3c). Microcystin containing blooms induced the degradation of chromatin leading to nuclear fragmentation in meristematic tissues: these tissues were characterized by healthy and apparently necrotic cells as well. The fragmentation of nuclei was accompanied by increased autofluorescence of cell walls (Fig. 3d). Using an excitation wavelength range of $540-580 \mathrm{~nm}$ we detected normal background autofluorescence of meris- 
(a)

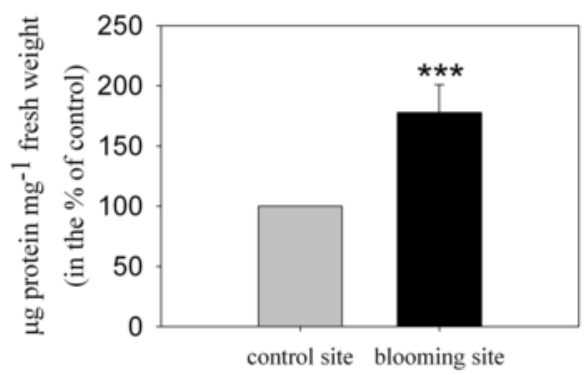

(c)

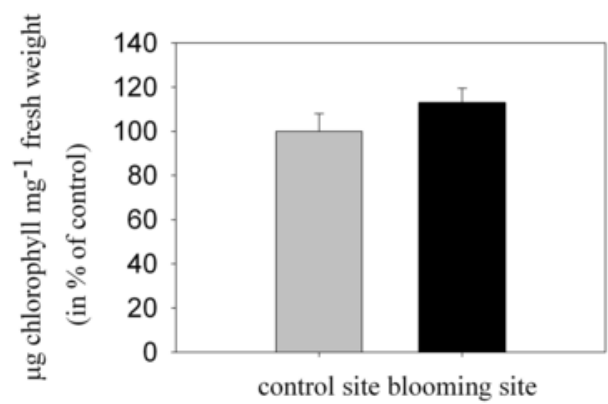

(b)

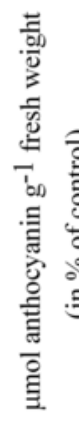

(d)

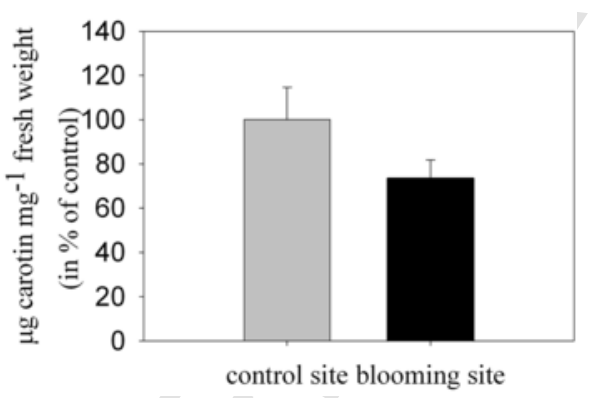

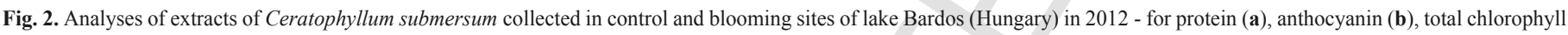
(c) and total carotenoid (d) contents. These compounds were assayed by spectrophotometry (see Materials and methods).

tematic cell walls of control plant samples. Additional autofluorescence of nuclei could be detected for plants collected from the HAB site (Fig. 3e-h).

Concerning the distribution of p-H3 Ser10 along control chromosomes of shoot tip meristematic cells, histone $\mathrm{H} 3$ phosphorylation could not be detected in interphase nuclei (data not shown). Phosphorylation started in prophase at the pericentromeric region of chromosomes, increased in prometaphase, then p-H3 Ser10 label culminated in metaphase: strong label was detected at the pericentromeric regions and slightly weaker label in chromosome arms. There was a gradual decrease of label at the end of mitosis (Fig. 4a, control site). For shoot tip meristems of plants collected from the HAB site, the pattern of histone $\mathrm{H} 3$ phosphorylation at Ser 10 was apparently similar in the sense that label culminated in metaphase. However at this stage of mitosis, p-H3 Ser10 label was visibly stronger than in controls (Fig. 4a, b). The AIOD value was $26.95 \pm 4.06$ for the control site and $38.02 \pm 4.06$ for the HAB site and the difference between these two values proved to be significant $\left(P^{<} 0.05\right)$. Moreover, strong label was uniform along chromosomes, that is, pericentromeric regions and chromosome arms contained phosphorylated histone $\mathrm{H} 3$ in similar amounts (Fig. 4a, blooming site).

\subsection{Peroxidase, nuclease and protease activities of plant samples}

Using a spectrophotometric method, the highest peroxidase activities were measured at $\mathrm{pH} 7.5$ (the activities were lower at $\mathrm{pH} 4.2$ and the lowest at $\mathrm{pH} 8.0$, data not shown). In the extracts of the plants of control site high POD activity $(3278 \pm 196 \mathrm{mM}$ oxydized pyrogallol min ${ }^{-1} \mathrm{mg}^{-1}$ protein) was measured at $\mathrm{pH} 7.5$. In plants of HAB site significantly $\left(P^{<} 0.5\right)$ lower enzyme activities were measured than of control site, the decrease measured at pH 7.5 was $40 \%$ (Fig. 5b). Native gels revealed a single main peroxidase activity band for plants of both sampling areas with higher activity in the plants from the control area (Fig. 5a) (see Table 2).

We detected characteristic nuclease isoenzymes of about $300-150 \mathrm{kDa}$ (Fig. 5c, d). The rationale of using pH6.8 for the detection of nucleases throughout this study was that in former experiments we could detect the highest activities at this $\mathrm{pH}$ in Ceratophyllum demersum, the closest relative species of Ceratophyllum submersum (Jámbrik, 2010). Furthermore it is generally known that the best studies on vascular plant nucleases can be performed at or around neutral pH (for example, see Yen and Green, 1991; Desai and Shankar, 2003; Jámbrik et al., 2011). Based on zymographies and their analysis we found that both ssDNase and dsDNase activities were significantly $\left(P^{<} 0.05\right)$ higher in plants of HAB site than in control site (Fig. $5 \mathrm{e}, \mathrm{f})$. The isoenzyme of high ssDNase activity was a protein of about $250 \mathrm{kDa}$, while protein detected on gels containing dsDNA was about $300 \mathrm{kDa}$ (Fig. 5c, d).

The activities of protease isoenzymes of $C$. submersum samples could be detected on gelatine zymograms (Fig. $5 \mathrm{~g}$, h). The most isoenzymes were detected by using an incubation buffer of $\mathrm{pH} 5.5$. 12-15 bands with gelatinase activities with molecular weights situating between 300 and $30 \mathrm{kDa}$ were detected in crude protein extracts of $C$. submersum samples and their detection depended on the presence of 2-mercaptoethanol (2-ME) (Fig. 5g). According to the measured band intensities, there were enzymes with lower activities in plants stressed by MCs than of control samples, these was for example the protein with $55 \mathrm{kDa}$ relative molecular mass (Fig. $5 \mathrm{~g}$; Table 1.). However, there were at least six enzymes with higher activities in plants of HAB site (see Fig. $5 \mathrm{~g}$; bands of about 205, 130, 110, 80, 65, $43 \mathrm{kDa}$; Table 1) than plants of control area. Overall, the total protease activities of these samples were significantly $\left(P^{<} 0.05\right)$ higher than the samples of control site (Fig. 5h). 

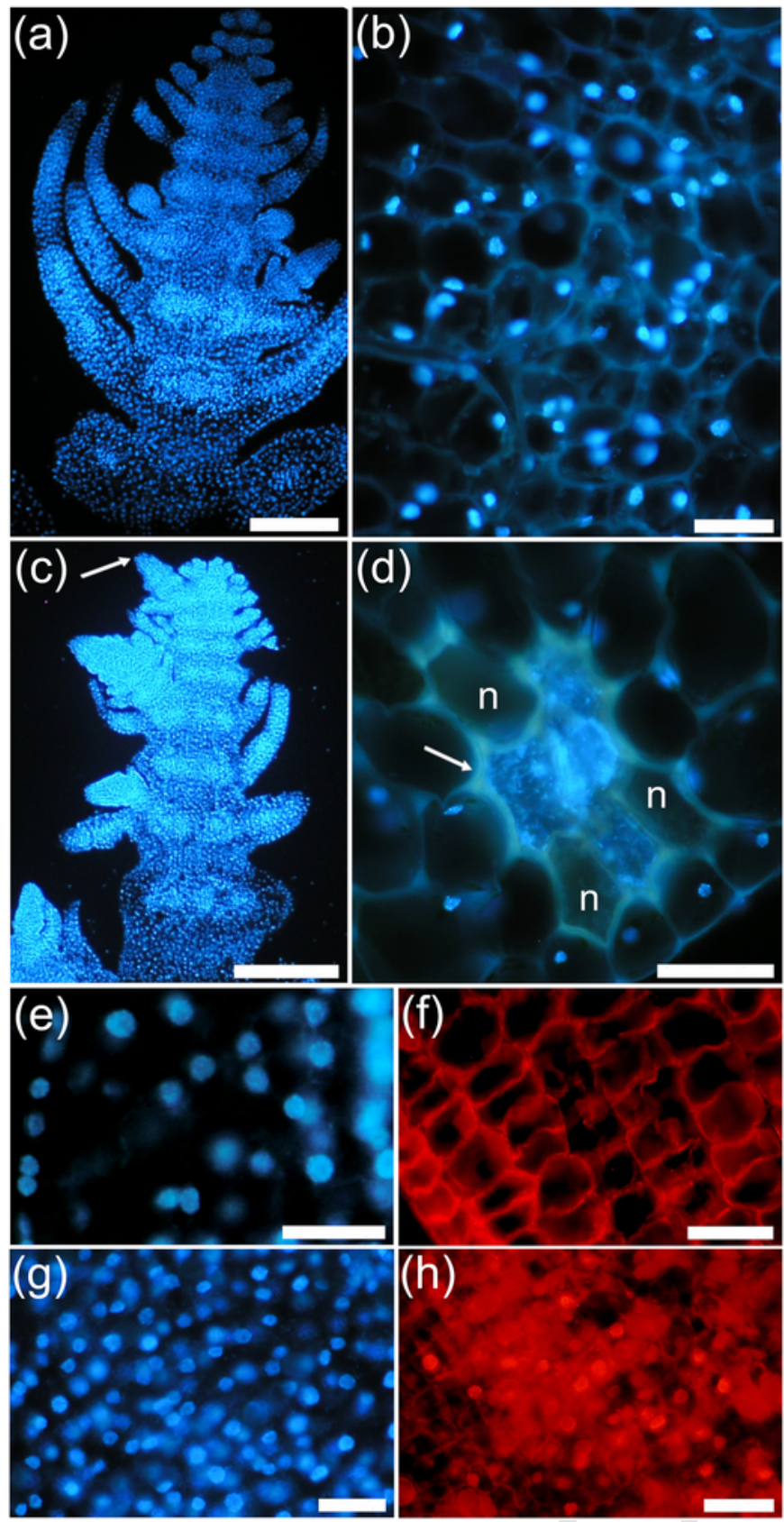

Fig. 3. Histological and cytological alterations induced by Microcystis blooming in $C$. submersum plants. (a) Shoot tip, control site; (b) section of young shoot, control site; (c) shoot tip, bloom (HAB) site: note swelling of shoot dome and early formation of lateral buds (arrow); (d) section of young shoot, HAB site: the formation of necrotic tissue. Note abnormal cell wall thickening (arrow), nuclear degradation in prenecrotic cells, and complete absence of DNA in necrotic cells (n). (e) Shoot tip section, control site showing DAPI stained nuclei; (f) same section, no autofluorescence of nuclei. (g) Shoot tip section, bloom site showing DAPI stained nuclei; (h) same section, autofluorescence of nuclei indicating the accumulation of oxidated aromatic (phenolic) compounds and nuclear localization of oxidative stress processes. Scalebars: $1 \mathrm{~mm}(\mathrm{a}, \mathrm{c}), 50 \mu \mathrm{m}(\mathrm{b}, \mathrm{d}-\mathrm{h})$.

\section{Discussion}

For Lake Bárdos, MC contents were relatively high both in the water body and in C. submersum plants at the HAB (blooming) site in 2012 and the highest as compared to water toxin contents in 2011 (a)

\section{pro prometa meta late ana/ telo}

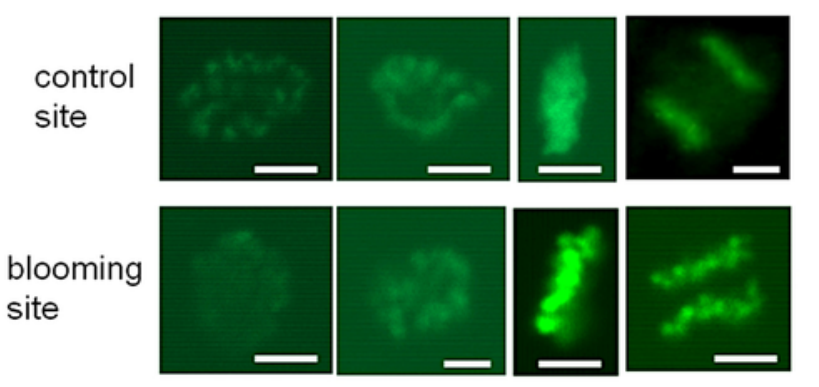

(b)

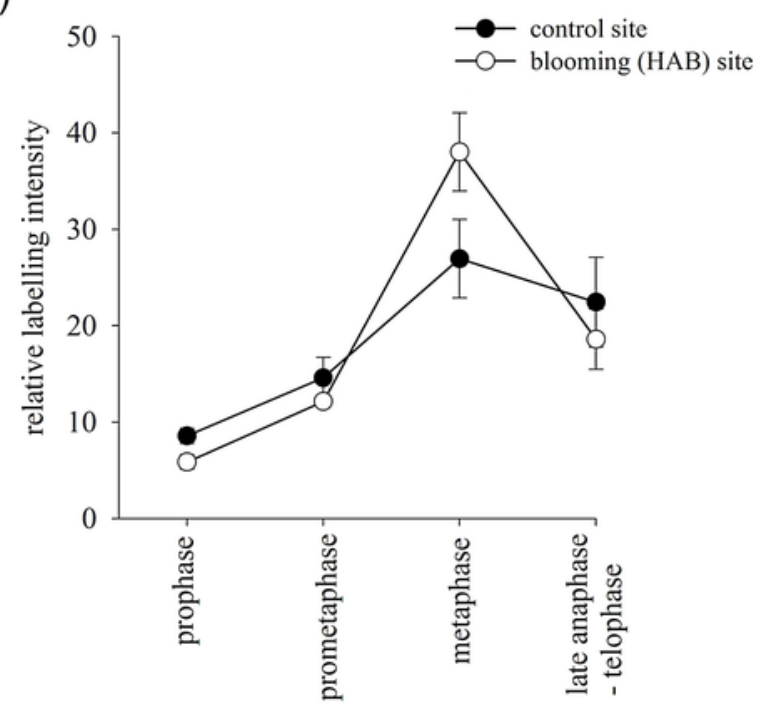

Fig. 4. Results of $\mathrm{pH} 3$-Ser10 labeling. (a) Representative confocal microscopy images of labels for mitotic phases in C. submersum shoot apical meristems, upper row - control site, lower row - blooming (HAB) site. Scalebars: $5 \mu \mathrm{m}$. (b) Quantification of labeling revealed histone $\mathrm{H} 3$ hyperphosphorylation in metaphase chromosomes of plant samples taken from blooming (HAB) site.

and 2013 (Fig. 1c and text/Results section). Indeed, the Blue-Green Sinapis Test (BGST) showed that the HAB formed in 2012 was the most toxic (Fig. 1b). It should be noted that the MC contents assayed in 2012 did not reach maximal values reported previously. These values were up to $35 \mathrm{\mu g} \mathrm{g}^{-1}$ dry weight for submergent, floating and emergent aquatic plants (Romero-Oliva et al., 2014; Pham and Utsumi, 2018), while freshwaters exhibiting HABs contain MCs in the $\mu \mathrm{gL}^{-1}$ range with rare cases of higher orders of magnitude $\left(\mathrm{mgL}^{-1}\right.$ range) (Corbel et al., 2014). For the above reasons, for the following studies, we concentrated on the C. submersum samples collected in 2012.

Pflugmacher (2002) grew Ceratophyllum demersum samples under laboratory conditions and treated with high, a "non environmentally relevant" concentration of MC-LR $\left(5 \mathrm{mgL}^{-1}\right)$ and after $24 \mathrm{~h}$ incubation plants became from dark green to pale yellow, lost their leaves and died. When they used lower, environmentally relevant MCs concentrations $\left(1.0 \mu \mathrm{gL}^{-1}\right)$ the significant reduction in growth was measured only after 6 weeks of exposure without pigment bleaching. However, after $24 \mathrm{~h}$ in $\geq 0.5 \mu \mathrm{gL}^{-1}$ MC-LR treated plants a switch in the ratio of Chl $a$ to $\mathrm{Chl} b$ was measured accompanied with the decrease in photosynthethic oxygen production. For the same 
(a)

(c)

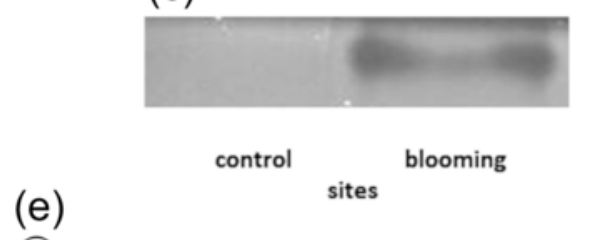

(e)

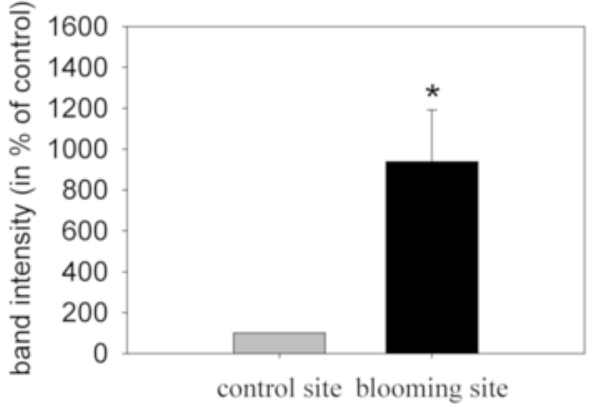

(g) $+2-M E$
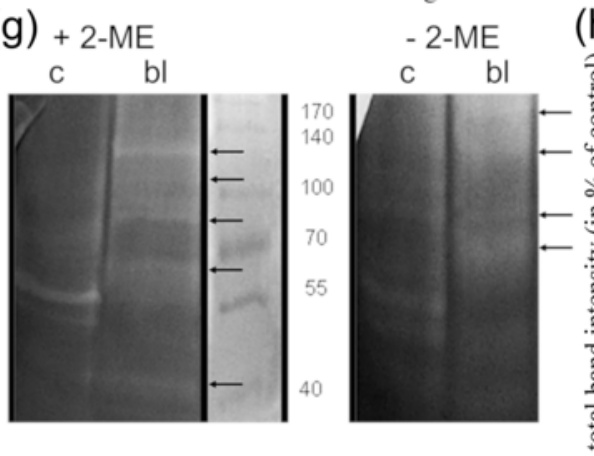

(b)

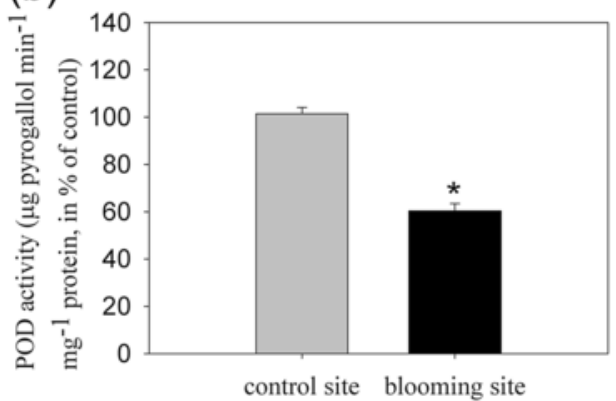

(d)
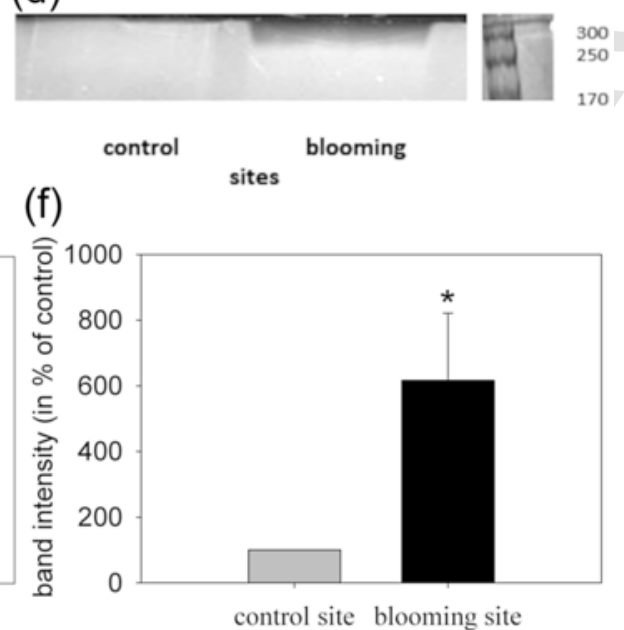

(h)

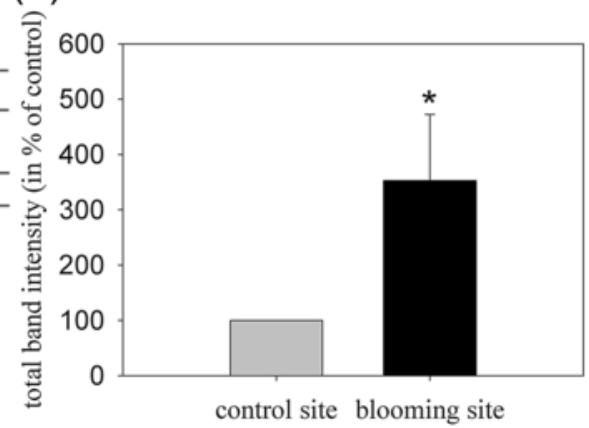

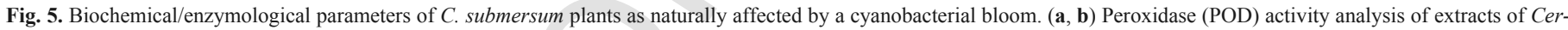

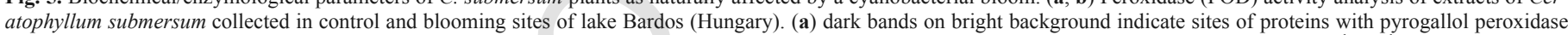

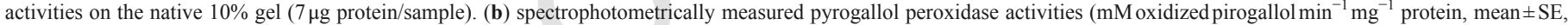

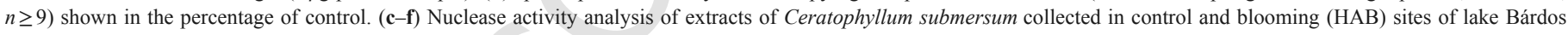

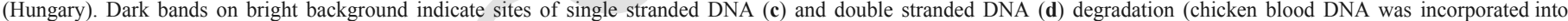

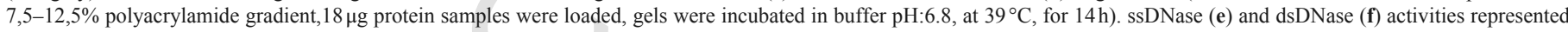

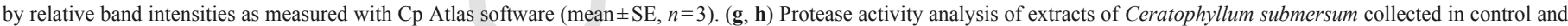

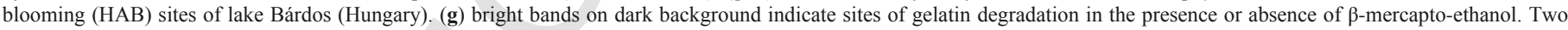

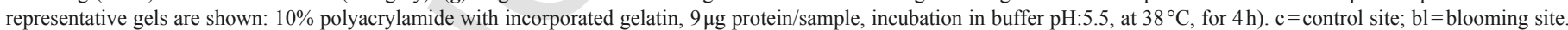

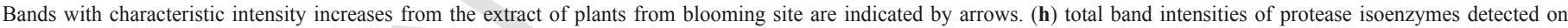

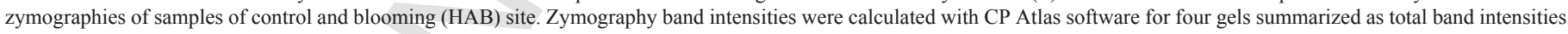
and shown as $\%$ of controls (mean $\pm \mathrm{SE}$ ).

species, Szigeti et al. (2010) proved a time- and dose-dependent growth inhibitory effect of purified MC-LR in a concentration range of $0.01-20 \mu \mathrm{g} \mathrm{mL}^{-1}(0.01-20.1 \mu \mathrm{M})$ at exposure times of $2-16 \mathrm{~d}$. Concomitantly with developmental and growth changes MC-LR decreased protein and chlorophyll content at $16 \mathrm{~d}$ of exposure: at $20 \mu \mathrm{g} \mathrm{mL}^{-1}$ of cyanotoxin, protein content was reduced to $53.3 \pm 2.8 \%$, while total chlorophyll content to $46.53 \pm 2.7 \%$ of controls. The present study shows that despite the relatively high total
MC concentration in both water and plant samples, concentrations of chlorophylls and relative ratios of chlorophyll $a$ and chlorophyll $b$ did not show significant decrease/alteration as compared to controls. Results of laboratory experiments proved that in general, MC-LR treated plants became chlorotic, the concentration of total chlorophyll decreased in them (see a review of Máthé et al., 2013), but this effect depends on incubation time, concentration of MCs and sensitivities of different plant species used in experiments (Pflugmacher, 2002; 
Table 2

Isoenzymes detected in the protease activity gels of extracts of plants from control and blooming site. + presence of the isoenzyme; $\uparrow$ increase of intensity as compared to control; $\downarrow$ decrease in intensity as compared to control.

\begin{tabular}{lll}
\hline Protease $\mathrm{kDa}$ & Plants of the control site & Plants of the blooming site \\
\hline$\geq 205$ & + & $\uparrow$ \\
130 & + & $\uparrow$ \\
$110-120^{\mathrm{a}}$ & + & $\uparrow$ \\
$90-100^{\mathrm{b}}$ & + & + \\
$80-85$ & + & $\uparrow$ \\
65 & + & $\uparrow$ \\
55 & + & $\downarrow$ \\
50 & + & $\downarrow$ \\
43 & + & $\uparrow$ \\
40 & + & + \\
37 & + & $\uparrow$ \\
\hline
\end{tabular}

${ }^{\mathrm{a}}$ Double.

b Triple bands on the overrunning gels.

Pflugmacher et al., 2007; Järvenpää et al. 2007; Saqrane et al., 2009). Pflugmacher (2002) established that the sensitivity of Ceratophyllum demersum to MC-LR is higher than of macroalgae (Cladophora sp.) or the emergent macrophyte $P$. australis measured by their photosynthetic oxygen production during a 24-h exposure. However, after 3 days in the time-course experiment a $50 \%$ recovery in photosynthetic oxygen production was detected, and after 6 days a near complete recovery to the original level was found despite the high/measurable MC-LR concentration in the tissues of $C$. demersum plants.

Anthocyanin concentration showed the greatest alterations among the studied pigments, its concentration in plants of the HAB site was significantly - by $>80 \%$ lower than in plants of the control site. Anthocyanin synthesis and accumulation in cotyledons is a characteristic process of Sinapis alba (mustard seedling) photomorphogenesis (Mohr, 1983; M-Hamvas et al., 2003, 2010). In our earlier work we demonstrated that $\geq 1 \mu \mathrm{g} \mathrm{mL}^{-1}$ MC-LR significantly reduced the anthocyanin content in the cotyledons on the 4th and the 8th day of treatments, which was opposite to the effects induced by environmental stress, like lack of phosphorous, nitrogen, sulfur, effect of UV-B, heavy metals or pathogen attack (Hodges and Nozzolillo, 1996; Wharton and Nicholson, 2000; Hale et al., 2001).

In plants of HAB site we measured higher soluble protein content than in plants of the control area. Similarly, lettuce plants experimentally irrigated with microcystin containing water showed slight increases of protein content (Bittencourt-Oliveira et al., 2016).

Since increases of protein content as well as decreases in anthocyanin content and the carotenoid/chlorophyll ratio are clear indicators of (both biotic and abiotic) stress reactions in vascular plants (Guy, 1990; M-Hamvas et al., 2003; Gunes et al., 2007), we can state that the toxic cyanobacterial bloom induced significant changes in the general state of $C$. submersum plants collected in the HAB site. These results anticipated that $\mathrm{MC}$ content in the water sample will induce histological, cytological and biochemical changes as well.

Increased nuclease and decreased peroxidase activities observed for $C$. submersum plants from the HAB site suggest a phenomenon generally occurring in plants exposed to biotic or abiotic stress. That is, the capacity of scavenging reactive oxygen (ROS) species decreases, leading to increased nuclease activities involved in the formation of single- and double stranded DNA breaks. Such nucleases may have two main functions: they are involved in DNA repair and/or the induction of programmed cell death (PCD) (Reddy et al., 2004; Jámbrik et al., 2011). Our cytological data are well related to the above biochemical changes. MC bloom induced the formation of necrotic cells in $C$. submersum shoot tips characterized by chromatin disorganization and DNA fragmentation. Excessive cell wall thicken- ing was also observed in the cells with fragmenting nuclei (Fig. 3d). Alterations at the nucleus level are characteristic for PCD and necrosis and it is induced by the concerted increase of certain protease and nuclease activities (Kusaka et al., 2004) observed in this study as well (Figs. 3, 5). Moreover, MC bloom induced nuclear autofluorescence (Fig. 3h). Autofluorescence of plant subcellular structures is believed to be caused by the accumulation of phenolic compounds causing oxidative damage (Kosslak et al., 1997). This is in agreement with the possible decrease of ROS scavenging capacity of these MC exposed plants (Fig. 5a, b). PCD, necrosis and the cease of normal cell growth is accompanied by microtubule depolymerization or reorientation as well (Bagniewska-Zadworna, 2008; Jámbrik et al., 2011). Plants of the HAB site were characterized by deformations of shoot tip morphology (radial swelling) leading to shortening of internodes and premature development of lateral buds (Fig. 3c). We have detected similar alterations in $C$. demersum plants exposed to purified MC-LR under laboratory conditions. These morphological changes were attributed to microtubule reorientations (Szigeti et al., 2010). Thus, we raise the possibility that cytoskeletal damage could be the reason for plant morphological changes under field conditions, too.

The pattern of histone $\mathrm{H} 3$ phosphorylation at Ser10 in control $C$. submersum meristematic cells followed the general rule for plant cells (Manzanero et al., 2002; Houben et al., 2007). That is, chromatin of interphase cells showed no detectable p-H3 Ser10 label. Prophase cells were characterized by weak signal that gradually increased with a maximum in the pericentromeric regions of metaphase chromosomes. Histone $\mathrm{H} 3$ phosphorylation decreased gradually at late mitosis (Fig. 4). For plants from the HAB site, hypercondensation and strong/uniform labeling of whole metaphase chromosomes could be observed (Fig. 4). This indicates histone H3 hyperphosphorylation induced by $\mathrm{MC}$, a potent protein phosphatase inhibitor. In general, the proper phosphorylation of histone $\mathrm{H} 3$ is required for chromosome cohesion at early mitosis and normal sister chromatid segregation at late mitosis. Its hyperphosphorylation may lead to altered segregation and in consequence, aneuploidy (Zhang et al., 2005) as observed in plant cells treated with MC-LR under laboratory conditions (Beyer et al., 2012). We can state that histone $\mathrm{H} 3$ hyperphosphorylation is at least partially caused by the inhibition of its dephosphorylation by MC and can be used as a marker of specific effects of this cyanotoxin under field conditions. Thus, the change in the phosphorylation state of histone $\mathrm{H} 3$ represents a key finding of this study, because it can be related directly to the presence of MCs in the water body and plants.

With the aid of activity gels, we detected higher ssDNase, dsDNase and protease activities in plants of HAB area than of control one. Under laboratory conditions, we detected elevated ssDNase, dsDNase and protease activities in MC-LR treated Wolffia arrhiza, Lemna minor, Phragmites australis and Ceratophyllum demersum (M-Hamvas et al., 2008; Jámbrik et al., 2010, 2011). C. submersum DNases with increased activity at the HAB site are of high MW. We suggest this high MW nuclease activity band results from a multimeric complex, because such complexes are frequently described for nucleases (see Desai and Shankar, 2003 for a review).

Between 300 and $30 \mathrm{kDa}$ molecular mass $12-15$ bands with gelatinase activities were detected in crude protein extracts of $C$. $s u b$ mersum at pH5.5 (Fig. 5g). Overall, the total protease activities of these samples were much higher than the samples of control site (Fig. $5 \mathrm{~h}$ ). High MW (above $80 \mathrm{kDa}$ ) proteases are of particular interest. Under laboratory conditions, these proteases were induced in $C$. demersum cultures treated with $20 \mu \mathrm{g} \mathrm{mL}^{-1} \mathrm{MC}$-LR for 5 days (Jámbrik, 2010). Solomon et al. (1999) points out that activation of high MW proteases can be related to plant programmed cell death. However (as 
for nucleases) we cannot exclude the possibility of the presence of high MW multimeric protease complexes in the C. submersum samples. Such complexes were previously described in higher plants (Piechota et al., 2010).

To sum up data on nuclease and protease activities, it is probable that the activity of enzymes related to cell death was increased in plants growing at the HAB site, which explains the direct or indirect cytological alterations observed and that can also be related to cell death: chromatin fragmentation, increase of autofluorescence in nuclei and possible microtubule depolymerization.

As a conclusion, the MC containing HAB site of Lake Bárdos, Hungary, affected C. submersum plants living at this site in 2012, at several levels. In this year significant total MC content was observed both in water body and in plants at the HAB site. Decreases of pigment levels (carotenoid-carotenoid/chlorophyll ratio and anthocyanin content) and of pyrogallol peroxidase activity indicated decreased stress defence capacity of the plants. The above parameters, together with the increase of protein level are clear indicators of biotic stress induction. The radial swelling of shoot tips and abnormal lateral bud formation at the shoot apex probably indicated alterations in cytoskeletal organization. This phenomenon, together with chromatin fragmentation and increased autofluorescence of nuclei as well as abnormal secondary cell wall thickenings and increased nuclease/protease activities indicated clearly that MC content of water body could induce cell death in this plant. One of the most relevant alterations observed was hyperphosphorylation of histone $\mathrm{H} 3$ in metaphase cells of plants from the HAB site, because this can be related directly to the potent protein phosphatase inhibitory effect of MC. Thus, hyperphosphorylation of histone $\mathrm{H} 3$ might be an indicator of the presence of a protein phosphatase inhibitory toxin in a given natural water body. To our knowledge, to date this is one of the first complex studies showing natural effects of cyanobacterial toxins on vascular plants under real environmental conditions.

\section{Acknowledgements}

This work was supported by the Hungarian Scientific Research Fund grants NKFIH K120638 to CM and K119647 to GV and co-supported by the EFOP-3.6.1-16-2016-00022 and GINOP-2.3.3-15-2016-00021 projects. The authors would like to thank Erzsébet Barna, Kitti Ajtay and Orsolya Geda for their excellent technical assistance. A.Z.U., M.R. and T.G. were supported by the NKA TÁMOP 4.2.4.A/2-11-1-2012-0001 Eötvös Scholarship Programme for talented students.

\section{Conflict of interest statement}

The authors declare there is no commercial or professional conflict of interest related to the contents of this work.

\section{References}

Babica, P., Bláha, L., Maršálek, B., 2006. Exploring the natural role of microcystins - a review of effects on photoautotrophic organisms. J. Phycol. 42, 9-20. https://doi. org/10.1111/j.1529-8817.2006.00176.x

Bagniewska-Zadworna, A., 2008. The root microtubule cytoskeleton and cell cycle analysis through desiccation of Brassica napus seedlings. Protoplasma 233, 177-185. https://doi.org/10.1007/s00709-008-0001-z.

Beyer, D., Tándor, I., Kónya, Z., Bátori, R., Roszik, J., Vereb, G., Erdődi, F., Vasas, G., M-Hamvas, M., Jambrovics, K., Máthé, C., 2012. Microcystin-LR, a protein phosphatase inhibitor induces alterations in mitotic chromatin and microtubule organization leading to the formation of micronuclei in Vicia faba. Ann. Bot. 110 797-808. https://doi.org/10.1093/aob/mcs 154 .

Bittencourt-Oliveira, M.C., Cordeiro-Araújo, M.K., Ahii Chia, M., Arruda-Neto, J.D.T., Tiago de Oliveira, , dos Santos, F., 2016. Lettuce irrigated with contami- nated water: photosynthetic effects, antioxidative response and bioaccumulation of microcystin congeners. Ecotoxicol. Environ. Saf. 128, 83-90. https://doi.org/10. 1016/j.ecoenv.2016.02.014

Bownik, A., 2016. Harmful algae: effects of cyanobacterial cyclic peptides on aquatic invertebrates-a short review. Toxicon 124, 26-35. https://doi.org/10.1016/j. toxicon.2016.10.017.

Bradford, M.M., 1976. A rapid and sensitive method for the quantitation of microgram quantities of protein utilizing the principle of protein-dye binding. Anal. Biochem. $72,248-254$.

Campos, A., Vasconcelos, V.M., 2010. Molecular mechanisms of microcystin toxicity in animal cells. Int. J. Mol. Sci. 11, 268-287. https://doi.org/10.3390/ ijms 11010268 .

Carmichael, W.W., 1992. Cyanobacterial secondary metabolites - the cyanotoxins. J. Appl. Bacteriol. 72, 445-459.

Corbel, S., Mougin, C., Bouaïcha, N., 2014. Cyanobacterial toxins: modes of actions, fate in aquatic and soil ecosystems, phytotoxicity and bioaccumulation in agricultural crops. Chemosphere 96, 1-15. https://doi.org/10.1016/j.chemosphere.2013. 07.056.

Desai, N.A., Shankar, V., 2003. Single strand-specific nucleases. FEMS Microbiol. Rev. 26, 457-491.

Farkas, O., Gyémánt, Gy, Hajdu, G., Gonda, S., Parizsa, P., Horgos, T., Mosolygó, , Vasas, G., 2014. Variability of microcystins and its synthetase gene cluster in Microcystis and Planktothrix waterblooms in shallow lakes of Hungary. Acta Biol. Hung. 65, 227-239. https://doi.org/10.1556/ABiol.65.2014.2.10.

Gunes, A., Inal, A., Alpaslan, M., Eraslan, F., Bagci, E.G., Cicek, N., 2007. Salicylic acid induced changes on some physiological parameters symptomatic for oxidative stress and mineral nutrition in maize (Zea mays L.) grown under salinity. J. Plant Physiol. 164, 728-736. https://doi.org/10.1016/j.jplph.2005.12.009.

Guy, C.L., 1990. Cold acclimation and freezing stress tolerance: role of protein metabolism. Annu. Rev. Plant Physiol. Plant Mol. Biol. 41, 187-223.

Hale, K.L., McGrath, S.P., Lombi, E., Stack, S.M., Terry, N., Pickering, I.J., George, G.N., Pilon-Smits, E.A.H., 2001. Molybdenum sequestration in Brassica species. A role for anthocyanins?. Plant Physiol. 126, 1391-1402. https://doi.org/10.1104/ pp.126.4.1391.

Hodges, D.M., Nozzolillo, C., 1996. Anthocyanin and anthocyanoplast content of cruciferous seedlings subjected to mineral nutrient deficiencies. J. Plant Physiol. 147, 749-754. https://doi.org/10.1016/S0176-1617(11)81488-4.

Houben, A., Demidov, D., Caperta, A.D., Karimi, R., Agueci, F., Vlasenko, L., 2007. Phosphorylation of histone $\mathrm{H} 3$ in plants - a dynamic affair. Biochim. Biophys. Acta 1769, 308-315. https://doi.org/10.1016/j.bbaexp.2007.01.002.

Jámbrik, K., 2010. The Effects of Microcystin-LR and Cylindrospermopsin on the Growth, Protease and Nuclease Activities of Aquatic Plants, PhD dissertation (In Hungarian).

Jámbrik, K., Máthé, C., Vasas, G., Bácsi, I., Surányi, G., Gonda, S., Borbély, G., M-Hamvas, M., 2010. Cylindrospermopsin inhibits growth and modulates protease activity in the aquatic plants Lemna minor L. and Wolffia arrhiza (L.) Horkel. Acta Biol. Hung. 61, 77-94. https://doi.org/10.1556/ABiol.61.2010.Suppl.9.

Jámbrik, K., Máthé, C., Vasas, G., Beyer, D., Molnár, E., Borbély, G., M-Hamvas, M., 2011. Microcystin-LR induces chromatin alterations and modulates neutral single-strand-preferring nuclease activity in Phragmites australis. J. Plant Physiol. $168,678-686$.

Jia, J., Chen, Q., Lauridsen, T.L., 2016. A systematic investigation into the environmental fate of microcystins and the potential risk: study in Lake Taihu. Toxins 8 (170)https://doi.org/10.3390/toxins8060170.

Kim, S., Nguyen, G.H., Kim, S., Lee, J., Yu, H.-W., 2009. Evaluation of methods for cyanobacterial cell lysis and toxin (microcystin-LR) extraction using chromatographic and mass spectrometric analyses. Environ. Eng. Res. 14, 250-254. https:// doi.org/10.4491/eer.2009.14.4.250.

Komárek, J., Anagnostidis, K., 1998. Cyanoprokaryota 1.Teil: Chroococcales. In: Ettl, H., Gärtner, Heynig, H., Mollenhauer, D. (Eds.), Süßwasserflora von Mitteleuropa. Gustav Fischer, Jena, pp. 1-548.

Körner, S., 2001. Development of submerged macrophytes in shallow Lake Müggelsee (Berlin, Germany) before and after its switch to the phytoplankton-dominated state. Arch. Hydrobiol. 152, 395-409. https://doi.org/10.1127/archiv-hydrobiol/ $152 / 2001 / 395$

Kós, P., Gorzó, G., Surányi, G., Borbely, G., 1995. Simple and efficient method for isolation and measurement of cyanobacterial hepatotoxins by plant tests (Sinapis alba L.). Anal. Biochem. 225, 49-53. https://doi.org/10.1006/abio.1995.1106.

Kosslak, R.M., Chamberlin, M.A., Palmer, R.G., Bowen, B.A., 1997. Programmed cell death in the root cortex of soybean root necrosis mutants. Plant J. 11, 729-745.

Kusaka, K., Tada, Y., Shigemi, T., Sakamoto, M., Nakayashiki, H., Tosa, Y., Shigeyuki, M., 2004. Coordinate involvement of cysteine protease and nuclease in the executive phase of plant apoptosis. FEBS Lett. 578, 363-367. https://doi.org/ 10.1016/j.febslet.2004.10.101.

Laemmli, U.K., 1970. Cleavage of structural proteins during assembly of the head of bacteriophage T4. Nature 227, 680-685.

Manzanero, S., Rutten, T., Kotseruba, V., Houben, A., 2002. Alterations in the distribution of histone $\mathrm{H} 3$ phosphorylation in mitotic plant chromosomes in response to cold treatment and the protein phosphatase inhibitor cantharidin. Chromosom. Res. $10,467-476$. 
Máthé, C., M-Hamvas, M., Vasas, G., 2013. Microcystin-LR and cylindrospermopsin induced alterations in chromatin organization of plant cells. Mar. Drugs 168, 3689-3717. https://doi.org/10.3390/md11103689.

Máthé, C., Beyer, D., M-Hamvas, M., Vasas, G., 2016. The effects of microcystins (cyanobacterial heptapeptides) on the eukaryotic cytoskeletal system. Mini-Rev. Med. Chem. 16, 1063-1077.

M-Hamvas, M., Máthé, C., Papp, M., Grigorszky, I., Molnár, E., Vasas, G., Borbély, G., 2003. Microcystin-LR alters growth, anthocyanin content and single-stranded DNase enzyme activities in Sinapis alba L. seedlings. Aquat. Toxicol. 62, 1-9.

M-Hamvas, M., Jámbrik, K., Máthé, C., Vasas, G., Bácsi, I., Beyer, D., Borbély, G., 2008. The effects of microcystin-LR (cyanotoxin) on different aquatic plant species (in Hungarian). In: Proceedings of the 4th Environmental Science Conference of the Carpathian Basin, Debrecen, Hungary. pp. 247-252, ISBN 978-963-06-4626-0

M-Hamvas, M., Máthé, C., Vasas, G., Jámbrik, K., Papp, M., Beyer, D., Mészáros, I., Borbély, G., 2010. Cylindrospermopsin and microcystin-LR alter the growth, development and peroxidase enzyme activity of white mustard (Sinapis alba L.) seedlings, a comparative analysis. Acta Biol. Hung. 61, 35-48. https://doi.org/10. 1556/ABiol.61.2010.Suppl.5.

Mohr, H., 1983. Pattern specification and realization in photomorphogenesis. In: Shropshire, W., Mohr, H. (Eds.), Encyclopedia of Plant Physiology NS. Springer, Berlin, Heidelberg, New York, pp. 336-357.

Pflugmacher, S., 2002. Possible allelopathic effects of cyanotoxins, with reference to microcystin-LR, in aquatic ecosystems. Environ. Toxicol. 17, 407-413. https://doi. org/10.1002/tox.10071.

Pflugmacher, S., Codd, G.A., Steinberg, C.E.W., 1999. Effects of the cyanobacterial toxin microcystin-LR on detoxication enzymes in aquatic plants. Environ. Toxicol. 14, 111-115. https://doi.org/10.1002/(SICI)1522-7278(199902)14:1<111:: AID-TOX14>3.0.CO;2-3.

Pflugmacher, S., Wiegand, C., Beattie, C., Krause, E., Steinberg, C.E.W., Codd, G.A., 2001. Uptake, effects and metabolism of cyanobacterial toxins in the emergent reed plant Phragmites australis (Cav.) Trin. Ex Steud. Environ. Toxicol. Chem. 20, 846-852. https://doi.org/10.1002/etc.5620200421.

Pflugmacher, S., Aulhorn, M., Grimm, B., 2007. Influence of a cyanobacterial crude extract containing microcystin-LR on the physiology and antioxidative defence systems of different spinach variants. New Phytol. 175, 482-489. https://doi.org/ 10.1111/j.1469-8137.2007.02144.x.

Pham, T.-L., Utsumi, M., 2018. An overview of the accumulation of microcystins in aquatic ecosystems. J. Environ. Manag. 213, 520-529. https://doi.org/10.1016/j. jenvman.2018.01.077.

Piechota, J., Kolodziejczak, M., Juszczak, I., Sakamoto, W., Janska, H., 2010. Identification and characterization of high molecular weight complexes formed by matrix AAA proteases and prohibitins in mitochondria of Arabidopsis thaliana. J. Biol. Chem. 285, 12512-12521. https://doi.org/10.1074/jbc.M109.063644.

Reddy, A., Viswanatha Chaitanya, K., Vivekanandan, M., 2004. Drought-induced responses of photosynthesis and antioxidant metabolism in higher plants. J. Plant Physiol. 161, 1189-1202.

Romero-Oliva, C.S., Contardo-Jara, V., Block, T., Pflugmacher, S., 2014. Accumulation of microcystin congeners in different aquatic plants and crops - a case study from Lake Amatitlán, Guatemala. Ecotoxicol. Environ. Saf. 102, 121-128. https:// doi.org/10.1016/j.ecoenv.2014.01.031.
Saqrane, S., El Ghazali, I., Oudra, B., Bouarab, L., Dekayir, S., Mandi, L., Ouazzani, N., Vasconcelos, V.M., 2009. Detection of microcystin contamination by the measurement of the variability of the in vivo chlorophyll fluorescence in aquatic plant Lemna gibba. Toxicon 53, 9-14. https://doi.org/10.1016/j.toxicon.2008.10.004.

Schlereth, A., Becker, C., Horstmann, C., Tiedemann, J., Müntz, K., 2000. Comparison of globulin mobilization and cysteine proteinases in embryogenic axes and cotyledons during germination and seedling growth of vetch (Vicia sativa L.). J. Exp. Bot. 51, 1423-1433. https://doi.org/10.1093/jexbot/51.349.1423.

Solomon, M., Belenghi, B., Delledonne, M., Menachem, E., Levine, A., 1999. The involvement of cysteine proteases and protease inhibitor genes in the regulation of programmed cell death in plants. Plant Cell 11, 431-443.

Somdee, T., Somdee, A., 2015. Comparison of different anion-exchange chromatography resins for the purification of cyanobacterial microcystins. Water Sci. Technol. Water Supply 16, 1-8. https://doi.org/10.2166/ws.2015.108.

Szigeti, Z.M., Jámbrik, K., Roszik, J., M-Hamvas, M., Tándor, I., Beyer, D., Vasas, G., Vereb, G., Surányi, G., Máthé, C., 2010. Cytoskeletal and developmental alterations in Ceratophyllum demersum induced by microcystin-LR, a cyanobacterial toxin. Aquat. Bot. 92, 179-184. https://doi.org/10.1016/j.aquabot.2009.11.003.

Szöllösi, E., Oláh, V., Kanalas, P., Kis, J., Fenyvesi, A., Mészáros, I., 2010. Seasonal variation of leaf ecophysiological traits within the canopy of Quercus petraea (Matt.). Acta Biol. Hung. 61, 172-188. https://doi.org/10.1556/ABiol.61.2010. Suppl. 17.

Tokodi, N., Drobac, D., Meriluoto, J., Lujić, J., Marinović, Z., Važić, T., Nybom, S., Simeunović, J., Dulić, T., Lazić, G., Petrović, T., Vuković-Gačić, B., Sunjog, K., Kolarević, S., Kračun-Kolarević, M., Subakov-Simić, G., Miljanović, B., Codd, G.A., Svirčev, Z., 2018. Cyanobacterial effects in Lake Ludoš, Serbia - is preservation of a degraded aquatic ecosystem justified?. Sci. Total Environ. 635, 1047-1062. https://doi.org/10.1016/j.scitotenv.2018.04.177.

Vasas, G., Gáspár, A., Surányi, Gy, Batta, Gy, Gyémánt, Gy, M-Hamvas, M., Máthé, C., Grigorszky, I., Molnár, E., Borbély, G., 2002. Capillary electrophoretic assay and purification of cylindrospermopsin, a cyanobacterial toxin from Aphanizomenon ovalisporum by plant test (Blue-Green Sinapis Test). Anal. Biochem. 302, 195-203. https://doi.org/10.1006/abio.2001.5525.

Wellburn, A.R., 1994. The spectral determination of chlorophylls a and b, as well as total carotenoids, using various solvents with spectrophotometers of different resolution. J. Plant Physiol. 144, 307-313. https://doi.org/10.1016/ S0176-1617(11)81192-2.

Wharton, P.S., Nicholson, R.L., 2000. Temporal synthesis and radiolabelling of the sorghum 3-deoxyanthocyanidin phytoalexins and the anthocyanin, cyanidin 3-dimalonyl glucoside. New Phytol. 145, 457-469.

Wiegand, C., Pflugmacher, S., 2005. Ecotoxicological effects of selected cyanobacterial secondary metabolites a short review. Toxicol. Appl. Pharmacol. 203, 201-218. https://doi.org/10.1016/j.taap.2004.11.002.

Yen, Y., Green, P.J., 1991. Identification and properties of the major ribonucleases of Arabidopsis thaliana. Plant Physiol. 97, 1487-1493. https://doi.org/10.1104/pp.97. 4.1487.

Zhang, X., Li, X., Marshall, J.B., Zhong, C.X., Dawe, R.K., 2005. Phosphoserine on maize CENTROMERIC HISTONE H3 and histone $\mathrm{H} 3$ demarcate the centromere and pericentromere during chromosome segregation. Plant Cell 17, 572-583. https: //doi.org/10.1105/tpc.104.028522. 